\title{
Commentary: The first year-Are you ready?
}

Jinny S. Ha, MD

From the Division of Thoracic Surgery, Department of Surgery, Johns Hopkins Hospital, Baltimore, Md. Disclosures: Author has nothing to disclose with regard to commercial support.

Received for publication Oct 2, 2019; revisions received Oct 2, 2019; accepted for publication Oct 3, 2019; available ahead of print Dec 30, 2019.

Address for reprints: Jinny S. Ha, MD, Division of Thoracic Surgery, Department of Surgery, Johns Hopkins Hospital, 600 N Wolfe St, Blalock 240, Baltimore, MD 21205 (E-mail: Jha1@jhmi.edu).

J Thorac Cardiovasc Surg 2020;159:1163

0022-5223/\$36.00

Copyright (C) 2019 by The American Association for Thoracic Surgery

https://doi.org/10.1016/j.jtcvs.2019.10.021

The contract has been signed, and many graduating trainees look forward to embarking on the next stage of their career. The transition from resident learner to surgeon in practice is both daunting and exciting. The many hours in residency have prepared trainees to tackle clinical challenges ${ }^{1}$; on the other hand, however, new graduates feel less confident in the professional, business, and interpersonal skill sets needed to be successful and productive in their first faculty position. ${ }^{2}$ In their article in this issue of the Journal, Fiedler and Sihag ${ }^{3}$ identify the unique obstacles young surgeons face during this transition period and provide practical advice for navigating and overcoming these barriers.

A young surgeon should not wholeheartedly embody the word independent but rather should seek to build a support network to help this transition. Years of residency training has not adequately equipped trainees to handle the nonclinical aspects of starting a practice. Good mentorship can fill in these gaps. A study survey by the Society of Thoracic Surgeons Workforce on Thoracic Surgery Resident Issues Transition to Practice Task Force found that $84 \%$ of recent graduates of thoracic residency programs stated that a formal mentoring program would be beneficial. ${ }^{4}$ Although mentorship from a senior surgeon is vital, the benefits of seeking peer mentorship could be invaluable. This type of mentorship can reduce isolation and provide comradery and additional social support for the early-career surgeon in navigating this new phase. ${ }^{5,6}$

Understanding that each of these topics could be further explored, Fiedler and $\mathrm{Sihag}^{3}$ have given readers a great starting point for young surgeons to develop a fulfilling and successful career within cardiothoracic surgery. They provide useful additional resources for career development for readers to consider in more depth. With the unique challenges of the health care environment today and changes in

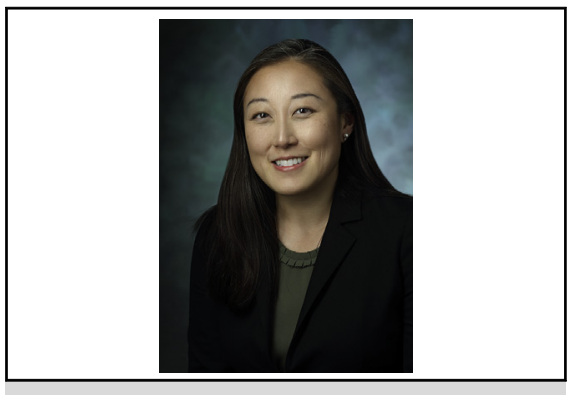

Jinny S. Ha, MD

Central Message

The transition to practice presents unique challenges for young surgeons. More tools are needed to increase the preparedness to practice for the early-career surgeon.

See Article page 1156.

the training paradigm, the "cookbooks" of the past for building a successful practice may no longer be as applicable. Further investigations are needed for a better understanding of this transition period for young surgeons in the current era. Data from these studies would help in the development of specific training tools needed to equip our trainees better for this next phase of their careers.

\section{References}

1. Odell DD, Macke RA, Tchantchaleishvili V, Loor G, Nelson JS, LaPar DJ, et al. Resident perception of technical skills education and preparation for independent practice. Ann Thorac Surg. 2015;100:2305-12; discussion 2312-3.

2. Cantor JC, Baker LC, Hughes RG. Preparedness for practice. Young physicians views of their professional education. JAMA. 1993;270:1035-40.

3. Fiedler AG, Sihag S. Entering the great unknown: transition to academic practice. J Thorac Cardiovasc Surg. 2020;159:1156-60.

4. Chu D, Vaporciyan AA, Iannettoni MD, Ikonomidis JS, Odell DD, Shemin RJ, et al. Are there gaps in current thoracic surgery residency training programs? Ann Thorac Surg. 2016;101:2350-6.

5. MacMillian TE, Rawal S, Cram P, Liu J. A journal club for peer mentorship: helping to navigate the transition to independent practice. Perspect Med Educ. 2016;5: $312-5$.

6. Bussey-Jones J, Bernstein L, Higgins S, Malebranche D, Paranjape A, Genao I et al. Repaving the road to academic success: the IMeRGE approach to peer mentoring. Acad Med. 2006;81:674-9. 